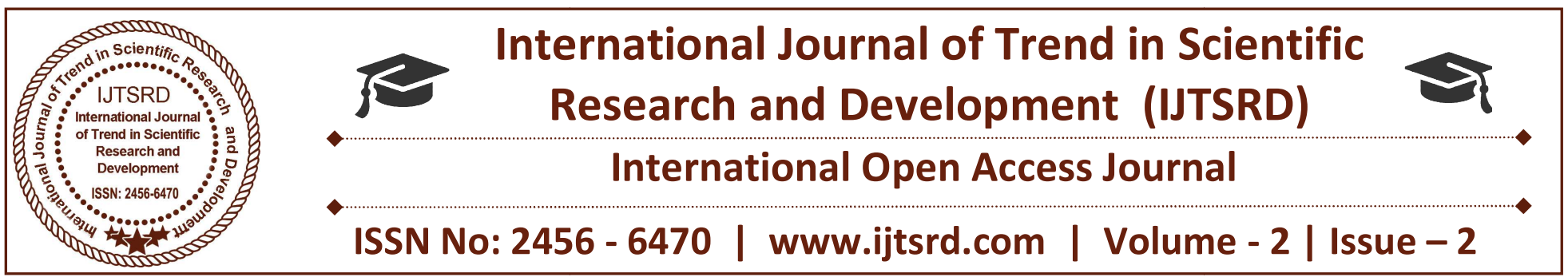

\title{
Conceptualising Innovative Jobs as Propeller to a High-Income Economy Status for Mauritius
}

\author{
Dr. Betchoo Nirmal Kumar \\ Dean of Faculty, Universite Des Mascareignes
}

\begin{abstract}
With the New Year already stepping in Mauritius, this research paper aligns with the Mauritian government policy for Mauritius to attain a high-income economy status by 2030. To achieve this, the researcher posits that innovative jobs could be the propeller of the economy. There is a need to scorn off white-collar jobs that have so far been a hallmark for personal and social achievement in the Mauritian society. Today's complex socio-economic environment calls for innovation and change for success. T/In / this perspective, this paper briefly describes the current dilemma of labour in Mauritius. It explains the need for graduates to be employable by considering flexible and adaptable employment possibilities. The paper concludes through scenarios like the creation of attractive jobs, the development of multi-skilled and polyvalent jobs, focused training and collaboration at work might frame a plausible case for the islandnation's stepping into a high-income industrialised and digitalized economy.
\end{abstract}

Keywords: job innovation, high-income economy, scenarios, middle-income trap, Mauritius

\section{Introduction}

As Mauritius steps into the New Year 2018, policy makers, business strategists and stakeholders among whom we must consider the common citizen, will continuously think of what Mauritius could better achieve in the year ahead. Since the island aims at becoming a high-income economy by 2030, the challenge to attain this coveted goal should be the aspiration of all governments including the

population. From different boards and committees, one hears of innovation and research as hallmarks to the stepping of Mauritius to a higher foothold. The argument here is how to get there and how these elements really seep into the mindset of the average Mauritian.

Seen from this perspective, innovation remains a challenge since from its very definition, the term implies developing something new from an already existing concept. As such, innovation is just a building up of some new concept from an already existing one. However, Hurley et al(2004) conclude that "creating a more innovative culture requires a change in the system, because people's beliefs about innovation are related to beliefs about other aspects of the system". Ideally, this would look quite simple given that all nations are capable of moving one step ahead from their previous position. The contest is how to create that new concept and how such innovation clearly shows an improvement from the previous position.

Can we speak of innovative jobs as we forward our wishes for prosperity and good health to all our citizens? Since jobs represent the factor that creates prosperity and well-being, could we have something in mind regarding innovation within jobs? This aligns with the philosophy that when people are asked what would improve the quality of their lives, the most frequent response is higher income supported by jobs (Campbell, 1981).Has this concept ever been tested and assessed in Mauritius? 


\section{White-collar jobs are overrated in Mauritius}

So far, most Mauritian families have some convergence regarding their siblings and their future. From manual jobs that children took over from their parents in the past, there is a movement towards more remunerative and privileged jobs that are basically white-collar. This is a concept embedded in Mauritian families with the intention of having children access to better education and higher paid jobs. Over time, prestigious white-collar jobs like educator, medical practitioner, lawyer, etc. have generated in an increasing demand for such occupations. Universities have provided opportunities for Mauritians to study both locally and abroad, and come back to serve the country in such attractive positions. Since the demand for highly-paid whitecollar jobs was flexible and expandable as the economy progressed, so was the eventuality to fill in such enviable positions and offer attractions like good pay, fringe benefits and related allowances to the incumbents. Autor (2011) confirmed that Long-term shifts in labour demand have led to a pronounced polarisation of job opportunities across occupations, with employment growth concentrated in relatively high-skill, high-wage and in low-skill, low-wage jobs - at the expense of "middle-skill" jobs.

\section{Getting Graduates employable in Mauritius}

Today, the equation is different and unemployment has stagnated at some $7-8 \%$ over the past decade. As a consequence, white-collar jobs, fewer in supply, are less capable of absorbing new labour that comes in with a larger number of qualified graduates with fairly similar demands; that is, the need to have a highlypaid job where pay and fringe benefits matter along with job security. Presently, the government is unable to fulfil such demands and vacancies are filled so quickly that a large number of qualified graduates remain either in temporary positions or are simply unemployed. Even if demand for graduates is growing the supply of graduates might as a result of the status derived from having a degree still exceed this. The demand for graduates itself need not be wholly tied in with upgrading of the labour force (Brynin, 2002).This has created high level of frustration particularly in prospective government jobs where there might be 8,000 applicants for a single or a few jobs with average wages to offer. It is now seen that post-graduates obtain a clerical job as a 'first come first serve offer' and this leads to frustration. Then the question is: What about being employed in a remunerative job and are there real prospects after all in Mauritius? Universities, per se, have become institutions offering graduate and post-graduate qualifications without ever assessing whether these would be fulfilled or not by employers and employees alike. Then comes the thought that the grass is greener elsewhere and that Mauritius is saturated in terms of employment and job prospects.

\section{Thinking of getting 'out of the middle-income trap'}

In parallel, the government will herald 'getting out of the middle-income trap' as the panacea for Mauritius that ambitions becoming a high-income economy. For reader's information, Gill and Kharas (2007) first coined the term "middle income trap" to describe apparent growth slowdowns in many former east Asian miracle economies. Along with other recent studies they raised the concern that sustaining growth through the middle income band requires significant reforms to the institutions of economic policy making and political processes (Yusuf and Nabeshima. 2009, Woo. 2009, Ohno. 2010). This is to some extent being evidenced by infrastructure development throughout the island followed by megaprojects stemming out in the form of smart cities. To this extent, it is important to think of the new job paradigm as a driver of such change. We definitely need semi-skilled and skilled labour in technical jobs but we also need specialisedlabour for high-end jobs. This is where the concept of innovative jobs will apply. The greater the innovation a potential job brings to the economy, the likelier is Mauritius able to propel itself to the desired position. Let us just think of e-business companies like Amazon or Aliexpress, both American and Chinese e-business giants. Such conglomerates have created new customer demands by privileging personalised and intimate sales to customers through computer-aided sales support. They have developed as major e-business organisations creating job opportunities for numerous people and developing high-skilled jobs for technicians capable of harnessing computer-based data coming from customer demands to invoicing and ultimately effective sales.

\section{Job innovation perspective}

This illustration purports the importance of job innovation as a change driver and a trigger for economic upliftment in the present and the near-future scenario. According to Kuznets (1966), a major thrust of modern economic growth is that massive structural 
changes in the economy and society are a necessary and integral part of the process of economic growth. This is because the economy-wide adoption of modern technology, in the context of similarlystructured human wants in all societies, engenders common patterns of change (Easterlin, 2001).It is rather risky to think quickly of robotisation and automation as propellers of change and advancement. These will be important accessories in new jobs but the fact is that jobs have to become innovative if Mauritius claims to enter the coveted league of highincome nations.

\section{Scenario planning for innovative jobs}

Certain scenarios can be envisaged. Firstly, jobs have to be attractive and command higher pay and employee satisfaction in the future. University graduates must expect to become more employable but also offer higher competences linked with information technology, the Internet of things along with highly technical knowledge in certain areas like engineering or big data management. This suggests that for work experience to be productive, it needs to be in a setting closely related to that of subsequent employment, a conclusion borne out by the Graduate Apprenticeship Programme (Fallows \& Weller, 2000).

Secondly, jobs have to become multi-skilled and polyvalent. Green (2000) suggests that employees frequently have to acquire multiple skills at different levels of complexity, as in vehicle manufacturing plants where production technicians move between functions as diverse as design, programming, maintenance, and operation. The white-collar managerial job concerned with board meetings and strategy will have to be partly reframed leading to managers who are active and capable of undertaking concrete on-the-job tasks while leading the workforce.

Thirdly, focused training should be encouraged when one thinks, for instance, of the blue economy and knowledge implications that it requires. Just sitting in the office and conceptualising ideas will not work. There is also the collaborative aspect in research and innovation needed at the institutional, academic and the State level. By working together in a highly interactive work context, organisational members gain an understanding of each other's' tasks and responsibilities and clearly recognize the interrelationships among jobs. Cooperation and cohesion among employees, managers, teams, functional units, and so on, are encouraged and supported such that they become institutionalized (Kozlowski \&Hults, 1987; Rosow\&Zager, 1988).For example, universities could avoid headlong competition and consider sharing knowledge and competences among themselves in an interdisciplinary perspective. Although the uniqueness of every institution matters, collaborative approaches to training and learning could help in the development of programmes that foster higher levels of cooperation which, in turn, develop tailor-made competences for the industry.

\section{Conclusion}

The minimum wage is now a reality in Mauritius and it helps overcoming poorly-paid jobs and high discrepancies between low and high-income earners. Also, the creation of innovative jobs that extend beyond the traditional ones should help in remunerating the qualified employee more attractively while developing interesting career paths. Alongside, we envisage that entrepreneurship is sustained in the new economy and that start-ups are given each and every chance to survive and contribute to the economy. An economics perspective is about achieving efficiency: "entrepreneurial action can overcome barriers to the efficient functioning of markets to contribute to the more efficient use of environmental and natural resources and the development of a more ecological sustainable economy" (Dean \& McMullen). Business facilitation, empowerment, training and financial incentives, among others, would certainly help young graduates accept new jobs, with a higher level of risk, with the scope of remaining prospective in the future.

In a nutshell, the ongoing question of job revalorization remains an essential concept to consider as from the next year and, bearing in mind, the eventual transition of Mauritius from an emerging economy to a high-income one. According to Zeithaml et al (1996), employees who are satisfied with their jobs are more likely to suit to their jobs as well. Low-paid jobs that are economical for the employer will still matter but might never help attain the desired target. Paying jobs better, seeking broader skills and competences from the worker along with the development of attractive career paths will matter. Baker and Huselid (1999) support that strong payperformance relationship is an essential element of a 
strategy that relies on people as a source of competitive advantage, not only for the effort elicited, but more importantly as a signal that the "right behaviours matter, and will be reflected in an employee's paycheck".

This is neither a dream nor a well-wisher initiative for 2018 but rather an argumentation to say that Mauritius must develop, train and retain its labour and human capital in the years ahead. The path to better days ahead will eventually come.

\section{References}

1. Autor, D. (2011) The Polarization of Job Opportunities in the U.S. Labor Market: Implications for Employment and Earnings, Community Investment, Vol 23 No 2.

2. Becker, B. and Huselid, M. (1999) Overview: Strategic Human Resource Management in Five Leading Firms, Human Resource Management, Winter 1999, Vol. 38, No. 4, Pp. 287-301.

3. Brynin, M. (2002), Graduate density, gender, and employment. The British Journal of Sociology, 53:

doi:10.1080/0007131022000000554.

4. Campbell, A. (1981) The sense of well-being in America. New York: McGraw-Hill.

5. Dean, T.J. \& McMullen, J.S. (2007). Toward a theory of sustainable entrepreneurship: Reducing environmental degradation through entrepreneurial action. Journal of Business Venturing,22, 50-76.

6. Easterlin, R. (2011) Modern Economic Growth: Rate, Structure and Spread, Review Essay Project 2011, Department of Economics, University of Southern California.

7. Fallows, S. \& Weller, G. (2000) Graduate apprenticeship scheme, in: S. Fallows \& C. Steven, (Eds)Integrating key skills in higher education(London, Kogan Page), 119-131.

8. Gill, I.S., and H.J. Kharas (2007)An East Asian Renaissance: Ideas for Economic Growth, World Bank.
9. Green, A. (2000) 'Lifelong Learning and the Learning Society: Different European Models of Organization'in A. Hodgson (ed) Politicies, Politics and the Future of Lifelong Learning,Kogan Page.

10. Hult, G., Tomas M., Hurley, Robert F. and Knight, Gary A. (2004) Innovativeness: Its Antecedents and Impact on BusinessPerformance. Industrial Marketing Management 33(5):429-38.

11. Kharas, Homi, and HarinderKohli (2011) 'What is the middle income trap, why docountries fall into it, and how can it be avoided?'Global Journal of EmergingMarket Economies3(3), 281-289.

12. Kozlowski, S. W. J., \&Hults, B. M. (1987). An exploration of climates for technical updating and performance. Personnel Psychology, 40, 539-563.

13. Kuznets, S. (1966) Modern Economic Growth: Rate, Structure and Spread. New Haven and London: Yale University Press, 1966.

14. Ohno, K. (2010) 'Avoiding the middle income trap: Renovating industrial policy formulation in Vietnam.'ASEAN Economic Bulletin26(1), 2543.

15. Rosow, J. M., \&Zager, R. (1988)Training: The competitive edge. San Francisco, CA: JosseyBass.

16. Woo, W.T. (2009) 'Getting Malaysia out of the middle-income trap.'Mimeo, Universityof California, Davis -Department of Economics.

17. Yusuf, S., and K. Nabeshima (2009)Can Malaysia escape the Middle-Income trap: AStrategy for Penang(World Bank).

18. Zeithaml, V.A., Berry, L.L. and Parasuraman, A. (1996), "Thebehavioural consequences of service quality",Journal of Marketing, Vol. 60, pp. 31-46. 